\title{
China's strategy in the Middle East (The Silk Road Project)
}

\author{
DR. Mohammad Salim Al-Rawashdeh. (Associated Professor), \\ International Relations, Al-Balqa'a Applied University, Princess Alia'a University College, \\ Hashemite Kingdom Of Jordan-Amman. \\ PROF. Mohammad Hamad AL-Qatatsheh. (FULL PROF) \\ MIDDLE EAST UNIVERSITY. POLITICS DEPT. Hashemite Kingdom of Jordan-Amman.
}

\begin{abstract}
The Silk Road was the title of a set of routes that were convoyed by caravans and ships between China and Europe, by a long of 10 thousand kilometers, which dates back to its beginnings to Han dynasty rule in China around 200 BC. Therefore China has launched in its international relations based on three strategies known as diplomacy, near the ocean «Peripheral Diplomacy», initiative and strategies, The New Silk Road is not just only lead to stimulate the economy but also to create new job opportunities for the youth sector in all participating countries in this way. It also contributes to a change of scenery geo-political, economic and geoEast and the Middle East with the formation of a new and powerful body weight behind stands is generally more serious repercussions for the policy of any external party affects the security and national strategies of the area residents.. The Middle East region has a strategic perspective of China's important in terms of the market two advantages: first, near the markets of the Chinese market compared to the US, European or African markets. The second provides purchasing power, especially in oil countries near the Middle East. so, China has strengthened efforts of some countries to revive the ancient Silk Road, it has been linked to some areas of China, Kazakhstan, as a first stage, were some of China's western provinces connecting train up to Germany and shorten the transition from China to the distance Europe from 36 days to 13 days to transport goods train through this.
\end{abstract}

Key words: China's strategy, Silk Road, Middle East region.

China's strategy in the Middle East (Silk Road Project)

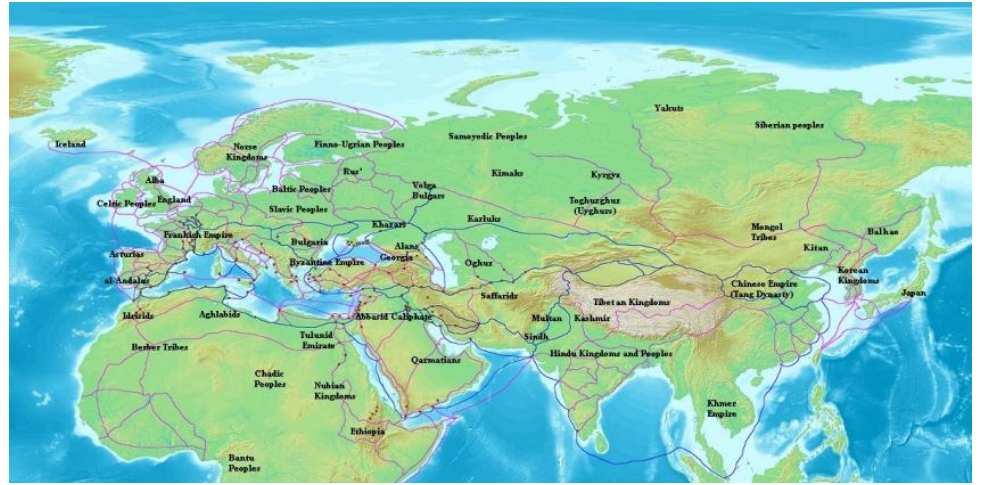

Map of the Route of the Silk Road.

\section{INTRODUCTION:}

The Chinese discovered the silk industry nearly in the year $3000 \mathrm{BC}$, and knew at this early time how to masterthis impressivearts and how to createits embroidery. This industry has stunned the minds of the people in the past; they sought for the acquisition of silk in various ways, so they were getting in return for its weight in precious stones. Five thousand years ago, silk route started to take from China to the world. Not only silk, of course, but many goods were spread with it, that were transited from China and the far reaches of Asia, to Central Asia, North Africa and Central Europe; which had taken specific pathways, known since ancient times as the Silk RoadBy "the ancient Silk Road, we mean as a set of land and sea routes that were taken by ships and caravans BC for the transfer of goods between Asia and the Middle East all the way to Europe for trade in Chinese silk, China has adopted a proposal to revive this route because of its strategic importance; where 65 countries would be sited on its track, reaching between the continents of Asia, Africa and Europe, and will 
cover about two-thirds of the world's population and a third of global. Under this framework, this paper tackles the Chinese initiative, highlighting some of the movements of countries in the region seeking to become a major focus on this road, and finally the impact of the initiative on economic and security scenes in the Middle East. In fact, the Silk Road was not one way, but a network of roads that are in greater ways or rather in two ways great, one north (summer) and the other winter were they follow in the winter time which combines all of these ways and tracks. They are the paths for the caravans from east to west, to pass on its way to countries. It soon flourished with the booming of this most famous trade route of the ancient world. Silk Road routes were organized since the fifth century BC, and they were regular for one thousand and five hundred years followed, where the Silk Road was culturally and socially route, expressing a profound impact in areas that passes by. The Silk Road did not stop at being a matter of trade between nations and ancient peoples, but exceeded (the global economy) to other humanitarian prospects, and moved through it many religions including Buddhism in the world Islam in Asia and passed through it (gunpowder) where nations knew devastating wars and passed through it ( paper) and there was a major breakthrough in human heritage with broad blogging activity that paper commanded it easily, and moved through it patterns of (social systems) which will continue to be, otherwise, buried in the capitals of central Asia, but economic activity, remained always the most important factor, and it had more correct impact. It is enough to demonstrate its impact and importance in the fact that the Silk Road led to the accumulation of the world's stock of gold in China, so that by the tenth century, China alone, possessed gold stocks more greater, owned by European countries together .The Silk Road was the title of a set of routes that were convoyed by caravans and ships between China and Europe, by a long of 10 thousand kilometers, which dates back to its beginnings to Han dynasty rule in China around $200 \mathrm{BC}$. It was so named in 1877 by a German geographer because Chinese silk was representing the largest proportion of trade through it. The Silk Road had a significant impact to the prosperity of many ancient civilizations, such as Chinese, Arabic, Egyptian, Indian and Romania, which extends from the commercial centers in the north of China that were divided into two sections. The northern branch passes through Eastern Europe and the Crimean Peninsula to the Black Sea down to Venice. The southern branch passes through Iraq and Turkey to the Mediterranean or across Syria to Egypt and North Africa. Silk Road has been stopped as a line of silk with a crew of Ottoman rule in Constantinople. But in the early nineties, attempts were started to create a new Silk Road, including what is known as the Asia-Europe land bridge, which connects China, Kazakhstan, Mongolia, Russia and up to the railroad iron to Germany. In December 2015 the new edition (in English) of the extensive study on the progress of the construction project of the continental bridge Eurasian was completed, a project that is the brainchild of Mr. Lyndon LaRouche and Mrs. Helga LaRouche .They are pioneers in this field in the last 20 years. The component of the report of 374 pages of large pieces and in English, entitled "New Silk Road becomes a global land bridge" intellectual and scientific to the new world economic order roadmap. The track on this road is led by group of BRICS countries (Brazil, Russia, India, China and South Africa), these states currently lead the global dynamics of optimism toward the real economic development accompanied by an integrated system of credit institutions and financial projects with very high technologies that would improve all of the humanitarian community. After the introduction planed by Helga LaRouche, the report presents "measures of progress" based on economic and scientific principles developed by the world economy physicist known for Lyndon LaRouche. The report then looks at one region of the world after the other, starting from China and Russia to submit a picture of the amazing progress and the plans that have been developed to implement the design of a land bridge Eurasian drawn up by the Government of China in 1996, as well as other nations, which began to join them.

In September 2013, and within a visit to Kazakhstan by Chinese President who announced a plan to establish a new Silk Road of China arrives to Europe known as the One Belt, One Road runs between the 60 countries with investments expected between 4 and 8 trillion dollars. The project aims to promote trade between Asia, Europe and Africa, along with a focus on world peace and prosperity of civilization of these countries. This might highlights the key role of Arab countries in the Middle East, specifically by virtue of its geographical location, which is also in line with the vision of the Arab countries saluted in 2030, which focuses on the exploitation of the geographical location of the area. The project aims to promote trade between Asia, Europe and Africa, along with a focus on global peace, economic, cultural, and political and civilization of these countries and prosperity. The Silk Road extends from China until the city (Antioch) Turkey, passing through Eastern Europe and the Crimea, even the Sea of Marmara and the Black and the Balkans, to reach Venice, and branching out from Turkestan and Khorasan, through Mesopotamia, Syria, Kurdistan and Anatolia, to the Mediterranean Egypt. Silk Road is a set of complex and interconnected roads that ships and caravans go through it. The Silk Road was called by this name because the silk which was flourished in China in the years BC, and began distributing in the world via the manifold ways, one of them is a summer overwhelmingly commercial roads carrying silk mainly in addition to other types of goods, and the other route is winter, were caravans pass from east to west, and that was the way the cause of the prosperity of countries and different civilizations, it has exceeded the importance of the road to being expressive of trading caravans, bringing culturally expressive and socially, and 
moved through it faiths such as (Buddhism) and (Islam) in Asia. And moved across the road (gunpowder), to spread destructive wars, and in return he moved through it (the paper) which lead to a leap in the field of science to become easily recorded. The Silk Road also contributed to the transmission patterns of behaviors, the cultural and social systems. Silk led to the accumulation of the world's stock of gold in China, and this shows how important it is, and who made the fortunes of China's gold more than they owned together of this precious metal in the European countries in its stores. And with the spread of Islamic Mughal wars, traders took the Maritime tracks from this road, because it is safer than the roads, and the road parameters disappeared little by little, and sea routes contributed to the Mamluk era in Egypt to flourish in an era of time, and find out the impact road (Cape of good Hope), in addition to the prosperity of Portugal and Spain. Extinguished Commerce in Egypt at the end of the Mamluk era and during the Ottoman period, until they were digging the Suez Canal, then it attended trade of new and changed course to come back there to flourish again. And the Silk Road is a transportation old road, extended across northern and western China and the whole of Asia, even up to Africa and Europe, and through it the(physical culture)moved to spread widely. Meanwhile, Silk was the main reason for the emergence of the road, and China's prosperity, and the acceleration of countries in the acquisition of Chinese silk, and interest in the road of weaving and decoration increased. The Roman poet (Leger) loved the Chinese silk, and described it by saying that the most beautiful of brightly colored flowers and finer than a spider weave. And Silk was a major cause of the spread of industries and other Chinese products to the world, and through the Silk Road, other countries promoted their industries were trade of material and mutual culture is due to this road. In the Roman era, the emperor (Octavius) seized on the Arabian Peninsula and the surrounding seas, and used the Silk Road way to this matter, but he failed in the end, and the impact of this encouraged Roman navigators to go to the Arab seas to get to India, and the exclusion of Arab mediation in India's Commerce and China. In other eras, and after research, this road has played a major role in political struggles, its objectives were purely economic, and concentrated in the Arab Middle East, and this was what happened in the Byzantine era, when the Byzantines tried with the help of the Ethiopians to control over China's trade and Indian profits, through the control of the Arabian Peninsula, and empowerment of the Ethiopians to seize Yemen. And we conclude that destroy the Ka'pa was not the main goal for (Abraha Ashram), but rather to control the Arabs and Algarihien, and so was economic motives and purely political.

\section{THE STRATEGIC GOALS OF THE SILK ROAD IN THE MIDDLE EAST:}

The last track of the relations of China's political and economic initiatives and military position shows that the "Middle Kingdom" has reached to a "greater Middle East." For several years now, China believes that energy security is very important to be left to market forces alone, and then made this issue a priority in terms of national security. China establish a foothold in Central Asia and the region, "the four seas" and the Middle East, through the projects ranging from pipelines and building new infrastructures and to growing calls from seaports. The country also increased its military ties to protect those interests. Moreover, if the way for this expansion is very much like " the old Silk Road." and the Arabian Sea that have brought China for the first time to the West. It was a big part of this activity is rooted in China's tendency to see the energy security of the views of the geopolitical strategy rather than just a purely economic point of view. Beijing was specifically concerned with confronting Western energy initiatives in the region. In 2009, for example, the "China National Petroleum Corporation," state-owned gas pipeline completed natural line through the "Central Asia" to Turkmenistan on the eastern shore of the Caspian Sea, at the same moment that it working there is a group supported by EU companies on Nabco pipe line to gain access to gas reserves in Turkmenistan from the West. In June 2010, President of Turkmenistan ,Gurbanguly Berdimuhamedov announced the project at a cost of \$ 2 billion to link the eastern pipeline with China, Western resources of Turkmenistan, which threatens the viability of the application of Nabuku.J pipeline Energy plans have faced in the theater, "NATO" in Afghanistan and neighboring competition from China as well. US companies and "the Asian Development Bank," have called much to the establishment of a gas pipeline from Turkmenistan passing through Afghanistan to consumers in Pakistan and India, that has culminated in a proposed project called "line across the gas Turkmenistan pipeline Afghanistan - Pakistan - India". However, the project should be at the level of the proposal rival Pakistan and India to get gas through pipelines from Iran. In March / March 2009, Tehran and Islamabad concluded share of a contract to build Iran-Pakistan "pipeline Iran-Pakistan-India" to bring in either New Delhi or Beijing to the project. Elsewhere in the region, China has entered the Iraqi theater of energy, which is now the biggest investor of oil and gas in that country.

\section{CHINA'S STRATEGIC SHIFT TOWARDS THE MIDDLE EAST.}

Since China became an importer state of energy in 1993, it has adopted a "going out" strategy to buy energy assets abroad, turning the old historic roads into a modern network of pipelines, roads and railways to supply its own energy. This approach stems from Beijing fears of US naval sanctions on supplies in the event of hostilities over Taiwan, as well as China's increasing demand for energy. A report in the August / August 2010 
showed that China has become the first energy consumer in the world, surpassing the United States. In addition, the country has enjoyed a tenth annual growth for most of the past decade, fueled not because of consumer demand, but due to the infrastructure and heavy industries buildings that consume energy, as well as increasing growth in the transport sector. Over the years, many journalists, policy makers and scientists to refer to this approach refer and talk about the "Silk Road" strategy. In contrast, Chinese officials have preferred this perception in order to evoke the common historical ties along the "Silk Road", while they seek to expand relations with the countries in Central Asia, the Caucasus and the Middle East. Moreover, in January 2010, China's State Council announced the establishment of "national energy committee" headed by Prime Minister Wen Jiabao, reflecting the deep concerns of the system toward energy security. To address those concerns, Beijing joined the "Shanghai Cooperation Organization" which was established in 2001, consists of China, Russia and Central Asian countries of the four Kazakhstan, Kyrgyzstan, Tajikistan and Uzbekistan, along with four controlling countries (, namely Iran, Pakistan, India and Mongolia). China has used the organization to achieve a gradual economic integration with the "Central Asia / Caspian" area and meet the three main objectives:

1. Soothing the inflamed province of Xinjiang which is home to the forces of "large Muslim Uighur" separatist.

2. Diversification of energy sources from the Arabian Gulf.

3. Show Chinese domination across Eurasia. This strategy is largely focused on the use of the financial means to create a dependency between regional governments, and building on the growing cooperation in the political and military fields, oil and gas.

In fact, as the Russian energy company, Gazprom, which is a state-owned, is using energy as a weapon by cutting off gas supplies to target specific countries if it refuses to foreign policy, Beijing sees energy as a weapon it must be used for repressive purposes.

Here, I would like to say that the Middle East region has a strategic perspective of China's important in terms of the market two advantages: first, near the markets of the Chinese market compared to the US, European or African markets. The second provides purchasing power, especially in oil countries near the Middle East. so, China has strengthened efforts of some countries to revive the ancient Silk Road, it has been linked to some areas of China, Kazakhstan, as a first stage, were some of China's western provinces connecting train up to Germany and shorten the transition from China to the distance Europe from 36 days to 13 days to transport goods train through this. The project of the new Silk Road aims to cross from China to Tajikistan and northern Iran, and then branches off to Iraq, Syria and Turkey, which promotes the transfer of Chinese goods to the Middle East in particular regions. Because of the American presence in this region, it may have a negative impact on China relations in the case of strained international relations or the occurrence of unexpected changes in the system. The purchasing power is to the great surge in the volume of trade between China and the region, trade between China and the region, the size has been increased from $\$ 36$ billion in 2004 to 107 billion in 2010 . However, the Chinese investment in the region is still modest compared to other regions (it is $1 \%$ in the Middle East, while 36\% in West Asia, 16\% in Europe, 15\% in the former Soviet republics, and 14\% in South.. etc) .it should be noted that China's trade volume of superiority since 2007 for the first time on the size of US trade with the region, something that US companies may push for more pressure on the government to put pressure on the markets of the Middle East on the one hand, and on China on the other hand, to improve its share of the Chinese military sales markets part of the forces of attraction in the Middle East market, where China occupies fourth place in the world in military sales volume for the region, its sales amounted to $2.1 \%$ of the total purchases region, which amounted to about 111 billion dollars.

The deployed Chinese energy investments spread a large scale to almost every corner in the "greater Middle East", especially in "Caspian basin" and other parties such as Iran, Turkey and Greece. In many cases, this economic expansion translated growing to a military foothold, due to the large-scale Chinese military personnel in the energy and "strategic partnerships" that Beijing set up projects with the key countries involved. Regarding Iran, between 2005 and 2010, Chinese companies signed contracts worth \$ 120 billion with the Iranian oil and gas sector. Iran has special importance to China because it has a border with the Caspian Sea and the Arabian Gulf. In the Gulf, Iran, Beijing sees as a way to achieve a balance with Arab countries supported by USA, by imagining that the US Navy is able to close the Gulf completely, as long Iran's ally to China dominate on the east side of it. Tehran is also a key player in the "silk Road" land and sea to China, where Beijing is looking to increase the links by rail lines, and perhaps even the establishment of a naval base in one of the Iranian islands. As for Saudi Arabia, more than half of Saudi Arabia's current oil is flowing to Asia, compared with 14 percent to the United States. And Saudi Aramco owns refinery in Qingdao province in China and another in Fujian Province, while Chinese companies have begun to invest in Arabian industry and infrastructure. At the same time, the Kingdom of Saudi Arabia is still China's largest commercial partner in the Middle East. On the military level, in the eighties of the last century, China has presented to the Saudis missiles, nuclear-capable aircraft "CSS-2", and Washington is concerned now that Riyadh may be seeking to create a deterrent against Iran acquiring more weapons designed by China, as well as nuclear warheads dual-use of 
Pakistan. Although the United States is still the main guarantor of the security of Saudi Arabia, but the kingdom seeks to achieve a balance in the face of Iran, which might become nuclear weapons through dealing with Beijing, Tehran's main ally. With respect to Iraq, Beijing has already increased the size of its investment in Iraq, which is now the biggest investor of oil and gas in that country, where it has signed on to develop a long service term oil fields as Rumaila and Hlvai, Maysan, either directly or through foreign companies that recently purchased decades. Given the Iraqi oil which is still in limited production and security problems and the lack of law on oil and gas. With this, China will continue to rely heavily on existing adult funders who are Saudi Arabia, Angola and Iran.

With regard to Turkey, In addition to its borders with both the Black Sea and the Mediterranean Sea, Turkey is a member of in the Old North Atlantic Treaty Organization [ "NATO", and enjoy the customs unity with the European Union, and is the main transit port for twelve projects lines multinational pipes. The strategic geographical location of the country is also an ideal location for rail networks connecting Europe to the Middle East and Asia. Consequently, when Chinese Prime Minister Wen Jiabao visited Ankara in October 2010, China raised the level of bilateral relations with Turkey to the "strategic cooperation."

When Jiabao's visit has come in the wake of the maneuvers, "Anatolian Eagle" joint air combat (carried out by the Chinese and Turkish troops) and the Peace Mission 2010's "Shanghai Cooperation Organization" (a military training to fight terrorism was in Kazakhstan). Traditionally maneuvers "Anatolian Eagle" exercises for NATO, "NATO" between Turkey and the United States and other members of the North Atlantic Treaty Organization, and Israel; but it seems that Ankara has preferred China to replace Israel.

Regarding Greece, In June 2010, the giant shipping company "COSCO" owned by China took over, full operational management and control on the main pier in the largest Greek port of Piraeus, which cost 2.8 billion pounds in the contract standing thirty-five years includes an planned expansion. Given that Greece controls the fifth of global trade fleet, the largest customer for Shipyards Chinese ships, this effort aims to promote Chinese trade with emerging markets around the Black and Mediterranean framework. China also plans to buy a stake in the heavily indebted railway OSE rail network and the building of an airport in Crete, and to build a logistics center in the north of Athens.

\section{MILITARY DIMENSIONS:}

The current Beijing-centric strategy to achieve a foothold on the Chinese presented by the military or geopolitical influence on the coastal strip along the Indian Ocean, and to the Persian Gulf and the Mediterranean Sea - in the "string of pearls." Located pearls that Beijing set up in recent years along the sea routes used for centuries to link China with the Mediterranean Basin. There are clear milestones include advanced facilities in the city of Port Sudan, among other facilities. As China has also added the Greek port of Piraeus as a new pearling the Mediterranean. In August 2010, Chinese naval vessels visited Piraeus when the Chief of Staff of the Greek Air Force Vassilios Klokosas met with Chinese Defense Minister Liang Guanglie in Beijing in the same month to discuss increased military cooperation. Elsewhere, Beijing hopes to establish a permanent naval base in the Gulf of Aden / Arabian Sea. The most likely option is the Yemeni port of Aden that other alternatives Oman and Djibouti - have close ties with NATO, "NATO" and Washington. China has also increased its military presence by land through the deployment of military personnel and police to monitor foreign construction projects. For example, it is several thousand soldiers deployed in Kashmir, Indian, raising concerns about China's efforts to link roads and rail projects in the "Karakoram Mountains," the port of Gwadar in Pakistan said.

\section{V. $\quad$ FOUR SEAS" STRATEGY}

At a time when Beijing embarks upon its strategy for the development of the "Silk Road" through to "look West" policy aims to "look east" policy on Syria to meet China in the Caspian Sea. Since 2009, the lion's enhances its strategy for "the four seas" to turn his country into a commercial hub in the Black Sea, Mediterranean Sea and the Arabian Gulf / Arabian Sea and the Caspian Sea, to go along with Turkey, Iran and Azerbaijan in the process. While Turkey stands out as the most important investor and trading partner for Syria, and Iran, where rest is the guarantor of the security of Syria, has become a three-Damascus-Tehran, Ankara kernel approach aims to include Iraq and the Caucasus in the contiguous series linking "the four seas."

While the West sees Syria and Iran and similar countries as obstacles strategy and rogue states, China sees these countries as assets strategy. Since the invasion of Iraq led by the United States in 2003, Beijing fears that Washington's strategy for "greater Middle East" involve encircling China and create a model to overthrow undemocratic regimes. In response, Beijing increased its economic and diplomatic ties with countries in the region have a problem with the United States and the West relations. One of the key components of the strategy, "the four seas" is to focus on energy infrastructure and the development of the railway. The energy level of Syrian President Bashar al-Assad to take steps to expand the "Arab gas pipeline" to transport gas from Egypt and Iraq via Syria, and at the same time with Azerbaijan and Russia on proposals to link the pipeline Nabco 
pipelines leading to Turkey and Europe. Moreover, through the linkage with Iran, it could be related to the "Arab Gas Pipeline" Ultimately pipeline Turkmenstan- China and lines of future oil pipeline between Kazakhstan and China. Moreover, China began to promote the revival of the ancient Silk Road in September 2013, where the president, "Xi Jinping", launched the "economic belt of the Silk Road Initiative and the Maritime Silk Road of the 21st century" under the slogan of "One Belt.. one way" to see the initiative light in 2049, and China started since then to take serious steps to activate this initiative, most notably the launch of the action plan for the silk Road, and the establishment of large financial entities to support it notably "ADB investment in infrastructure," \$ 100 billion of capital, with the participation of 57 countries China will contribute to the estimated $\$ 30$ billion, as the Chinese president after launching the initiative announced that his country will contribute $\$ 40$ billion to support infrastructure in the silk road.

With respect to the importance of the Middle East region of the Silk Road, the Chinese caravans passing in the ancient Silk Road necessitated them to cross through the area to get to Europe, and the Middle East is an important point for reaching quickly and access to the world via this route passing in Afghanistan and Iran and then branches off the road to the road to Basra, including the Arabian Gulf, and the second route up to Syria and the Mediterranean Sea and then Rome. For marine road of navigation, the Mumbai Port, India, which was receiving ships from Asia is a key point for the passage of some Arab countries, such as the fairway is divided into corridor it takes its way to the Arabian Sea, Arab Gulf Arab Arabian Peninsula and ports, the second route is through the Arabian Sea and up to the Aden, Yemen, including the land route starts along the Red Sea, to express Saudi Arabia and Jordan down to Gaza, and then cross the Mediterranean to the ancient Rome.

With the increase in hotbeds of tension in the region after the Arab Spring, there are several proposals to rely on a network of alternative routes, including the transit of Iran and the Arab Gulf, all the way to Saudi Arabia and Jordan, and Egypt's Mediterranean and Europe, or the sea route that would avoid the ports of Yemen, then him to the Red Sea and the Mediterranean Sea to Europe.

The Chinese initiative created kind of regional competition from nations seeking the region to be a major transit point on the Silk Road, and at the same time providing services to vessels transiting between East and West, as well as the great support infrastructure investments that will be allocated to these countries by the financial institutions that initiated and founded by china, as the attention of countries in the region the initiative not only economic and commercial benefits to be provided, but the political and security stability, which will pay the rest of the beneficiary countries of the way attention to ensure the security and stability of these countries.

\section{THE MOST MOVEMENTS OF THE REGION.}

Many countries in the region have sought to highlight their role in the success of the Chinese initiative, and occupy an important center on the road course, most recently Saudi Arabia and China signed in January 2016 a memorandum of understanding on strengthening cooperation regarding the economic belt of the Silk Road, and Qatar and China may have carried out the same step in November 2014, and included understanding the establishment of a specialized center in the clearing, and settlement, "yuan" Chinese in Doha, which will make Qatar the regional center for clearing the Chinese currency and resolution, which in turn contributes to make Doha an important axis in the initiative, at least financially. In the same content, the UAE seeks to give effect to the strategic partnership with China through high-level visits between the two countries in order to fill a pivotal role on the Silk Road, the last visit of Crown Prince of Abu Dhabi Sheikh Mohammed bin Zayed AlNahyan to Beijing in 12/13/201.In this regard, UAE also focuses to maximize the role of the sectors of the maritime and air transport in the Chinese initiative, where the bulletin "open skies" issued by the company "Emirates" indicated that the company is a prominent player on the "new silk road", where it is currently serving 30 countries, among 65 are located along this road, and in the same framework, "Dubai ports World," company announced it was in talks to invest in Iran, which has a land bridge good railway that will be linked to the silk road, which will help Dubai Ports in linking the focal points along the silk road and thus served an important role in the economic belt of the road. Regarding Kuwait, its location in the middle intersections of Silk Road gives it comparative advantage, especially since China views the island of "Boubyan" on the Arabian Gulf that it will support the chances of Kuwait to become a financial and commercial important axis between participating in the Silk Road Initiative countries, which prompted the two countries to sign a memorandum of understanding on the development of joint cooperation of the road in June 2014, as well as the city of "silk" under construction (near the Iraqi border) with the participation of China, where it is expected to contribute all in linkage with Central Asia and the Caucasus countries and, by extension presence on the map of the economic belt of the silk road.

For Egypt, it seeks to strengthen its role in the new road initiative by signing agreements with China, the last of which was the signing of Egypt and China Memorandum of Understanding on the Silk Road initiative in January 2016, including positioned to become an important hub in this project, supports the Egyptian moves 
The new Suez Canal Axis Development Project, which includes the establishment of industrial entities and logistical serving vessels and containers passing through the canal, which prompted several official Chinese bodies and informal proposal to establish a link between the Suez Canal project and the initiative of the economic belt of the silk road. Iran cannot be ignored, especially after the lifting of economic sanctions on it , and with its presence as a central point on the Silk Roads Initiative, signed a memorandum of understanding with China to develop cooperation on the Silk Road initiative in January 2016, as the focus Tehran focus on the completion of the railway mega-planned network created to link China with Europe, most recently the ongoing project planned "railway Iran-Armenia" with the participation of China, which will be incorporated in the silk road. For Turkey, it has focused its attention on the development of infrastructure and lines of land and navigation, especially in terms of planning for the project "land bridge Eurasian III," a huge a railroad linking the "Shenzhen" to the nearby port of Hong Kong, the countries of Asia, including Iran, and then passes into Turkey finishes in the Netherlands, and a line subsidiary will begin in Turkey through Syria, Palestine and Egypt, according to Turkish sources will be the opening of a railway linking Turkey, Georgia and Azerbaijan mid-2016 within this project, and on the other hand, Turkey supports its presence in the initiative by investing in its ports on the eastern coasts .

\section{THE NEW SILKROUTE AND THE FUTURE OF THE MIDDLE EAST REGION:}

The Middle East, from Iran to Turkey, Iraq and the Arabian Peninsula to Egypt a natural bridge between the continents of Asia, Europe and Africa, which qualifies it for the maximum benefit from the passage ways to transfer core technology goods through its territory and waters. This makes the cost of transport in the world where at least virtually. The problem of the Arab countries is that they are not tied together by the energy and water efficiently transports networks, thus depriving the vast regions of those states of development and investment in human and natural resources in the right way. Iran has done since 1996, when China announced the adoption of a draft new Silk Road to build a national network of railways and gas pipeline within the country with a strategic view make it the main port of nations closed in Central Asia to reach the international ports on the Gulf such as Bandar Abbas, for example. Iran has also become one of the main passing between China and Europe after successfully linking the railway network Hdidha with Turkey in 1998. It is also working to build and participate in the construction of the north-south passage between Russia and North Europe via the so-called Caucasus, Azerbaijan and Armenia to India and South Asia to the south, where it is working on the development of Chabahar port in the Arabian Sea near the border with Pakistan. The completion of the north-south passing will be shortened the process of moving goods three weeks compared transported by sea. Thus, Iran has made from its territory which cannot be a bridge to neighboring countries and regions in the east, west, north and the Indian subcontinent to be abandoned. It is unfortunate that the Arab countries have not taken any concrete steps at this level and keep the projects proposed by the LaRouche movement on the engineering office shelves waiting for the political decision. Perhaps the recent developments in Egypt and the government's decision to implement a set of giant infrastructure projects, a new start of the Arab dream. The decision to expand the Suez Canal open shunt or a new channel to become open to the transfer of the canal in both directions all the time is one of the most important projects that have been adopted in the past decades.

There were many skeptics in the feasibility of the Silk Road as a danger and a threat to the transfer between East and West through the Suez Canal alternative. As usual, it was the politicians, economists and skeptics who believe them count just what passes under their lands and cannot afford the expense of what is in the future. The enormous development in China and East Asia, India and Asia doubled many times so that the volume of world trade will not be enough of the Suez Canal and the new Silk to pass each of goods between East and West Road. The search is now on the additional routes across the North frozen Sea and Siberia to link the North Pacific and North Atlantic, northern Europe. What economists usually miss is that the subject is not the trade and transport of goods from point A to point B to the east in the west, but what is important is the area between the two points the whole development. Therefore, the Suez Canal project properly project that includes the construction of new industrial zones in the Canal Zone benefit from passers-by movement. Another important point to reflect the health outlook for the maker of the Egyptian decision today is that the funding be internally class basis and does not depend on the charity of the global financial institutions that are related to their decisions by political considerations kept Egypt and many other countries hostage dependency for more than three decades since the end of the era of Jamal Abdel Nasser. Therefore, it is an urgent requirement for Arab countries to begin planning joint infrastructure between the Arab countries for development projects as soon as possible, and to begin by asking their thoughts about building a joint Arab system for railways, roads, water projects, and the creation of an Arab Bank joint development allocated at least \$100 billion of that projects, and to be implemented as soon as possible. It can also help in financing the projects of European or Asian experiences in helping their establishment by signing "oil contracts in exchange for technology" with 
those countries, rather than direct monetary financing funding, as it is supposed localization of the head of the expatriate Arab money. Since Arab countries cannot rely on international institutions like the International Monetary Fund and World Bank; because, First: they are unable or unwilling to finance such projects, and secondly: loans are usually conditional terms detract from the national sovereignty of States.

\section{THE LAROUCHE MOVEMENT HAS PROPOSED TWO PARALLEL ACHIEVE TRACKS TO THIS GOAL:}

\section{First: the Silk Road}

The geographical location the Middle East is of in the heart of the Euro-Asian bridge, in addition to larger stocks of raw materials, where energy exists; it is passage for most international trade; they most primary products and manufactured between Asia and Europe pass through the Suez Canal ,Aqaba and Bab al-Mandab. To link the Arabs with Asia it must first be building a bridge for relations with the Islamic Republic of Iran, which has become a key to Euro-Asian Bridge, after the Iranian government has realized the importance of linking its economy with such giant idea and the importance of its role in it. Iran's former president, "Hashemi Rafsanjani" - with the participation of 12 heads of state and 50 representatives of governments from different parts of the world inaugurated on May 13, 1996 a railway line, linking the city of "Mashhad " in the north-east of Iran and "ferns" oasis in Turkmenistan, another of the "fern" to "Tajan" in Turkmenistan; where a vast network stretching across the former Soviet Union in the north to China in the east, and that Iran is actually have linked China and Asia to Europe; the same line that extends "from Tehran," the capital to the east towards Turkey; where Iran and Turkey update the line linking "Tabriz" and "Wan " in southeast Anatolia, and from there to Ankara, Istanbul and Europe. As for the south-east side; the work has been completed in Iran for the construction of a railway line connecting the Iranian network (Central Asia and Europe via Iran), Pakistan, and extends the line of the city, "Kerman" to "Zahedan" in the south-eastern border with Pakistan. When the line is complete, Iran would have linked Europe with the Indian subcontinent and Southeast Asia. And for the Arab countries; in addition to their disruption unbroken Bed from - Asia; the Arabs ignored the fact that the largest population bloc in the history of the world there are east of the country Arabic at a distance of 3,000 kilometers east of Baghdad, and this distance can be traveled by express train through less than two days. The biggest economic market in the world today exist in that area, it would be un wise for the Arabs not to take advantage of such an opportunity provided by Iran to link between them and the strategic market. Working has begun in Iran since a period of time to create a new iron rail line from Tehran to the city of "Pachtran" (Kermanshah) in the west of Iran, and from there the line will continue to the city, "Khosrawi" on the border with Iraq. At the same time there is in Iraq now a railway line that runs from Baghdad to the Iranian border close to the city, "Khanaqin" 200 kilometers distance northeast of Baghdad. This is a golden opportunity available for Iraq and Iran to open a page of economic cooperation, and turn the page of black war... Though the stated goal to build Tehran Khosravi line is to connect the capital region, which includes the cities of "Hamedan" and "Pachtran" thatrepresent an industrial arises territory, in addition to linking region in the Eastern province near the Iraqi oiland gas-rich border, which is a mainstay of energy production Iranian emerging industry. The larger goal; it is linking East Asia and Central Asia across Iraq and the Arab countries.

\section{CONTRIBUTION OF THE"PRODUCTIVE TRIANGLE"}

In terms of the idea of linking the Arab world to Europe; the creation of the "Silk Road" will be the most important factors that encouraged the Europeans to contribute to this project. But the most important prerequisite for achieving the proposals mentioned here is the application of "La Roche" program to develop the infrastructure "of the productive triangle "; where the cities of Paris, Berlin and Vienna represent the corners of this triangle in which resides the largest industrial technological density on the surface of the earth. The fate of the Middle East linked to the development of creating an "economic miracle" in the center of Europe by building a sophisticated system of transportation of railway and high-speed rail trains with magnetic lifting "Maglev Iron" and others. So Europe must cooperate with Japan and China to provide the technological margin required for the development of the Middle East, and includes the production units of conventional and nuclear power generation and water desalination on a large scale over the next 15-20 years, and in this context must improve infrastructure efficiency of transfer between North Africa and the Middle East to the productive triangle regions in Europe, and some of its components:

(1) Build a road transport across the Strait of Gibraltar.

(2) To extend the network of transport of goods and passengers from central Europe around the Mediterranean, in the form of a closed circle railway lines across Gibraltar to the North African coast, and through the Suez Canal to Palestine, Jordan, Syria, Lebanon, and Turkey to Europe again.

(3) Conduct a comprehensive improvement of the railway stretching from Turkey to Iraq and Iran, and from there to Asia. 
(4) Improve marine transportation and pipeline between Sicily and Tunisia, and retain the option of building a tunnel under the sea in the future.

\section{The proposed Arab projects}

One of the most important goals at the moment is to complete the rail lines and highways on the following main lines:

1-Istanbul - Mosul - Baghdad - Basra - KUWAIT Dhahran (Manama) - Doha, Abu Dhabi - Dubai - Muscat Salalah - Aden, known historically as part of the Berlin Baghdad line.

2-TEHRAN BAGHDAD Aleppo, Damascus (Beirut-Tripoli,Sour) - Amman West Bank- Gaza Alexandria, known as the Orient Express.

3-BAGHDAD Najaf,Hail-AlMadinaAlmnorh- Jeddah is known historically as the Zubaydah Road.

4-Istanbul-Aleppo, Damascus, Amman ,Jeddah, Makah- Gizan- Alhdidh- Mocha known as the Hijaz Road.

5-Of Alexandria, Aswan, Cairo, Khartoum, Addis Ababa, Djibouti, Nile line.

6-Alexandria, Tripoli, Sfax, Tunisia, Algeria, Region Fez and Tangier, Rabat, Morocco way.

Development of marine ferry lines across the Red Sea as it is supposed (Region Port Sudan and MkhaAssab), and across the Gulf (of Bandar Abbas and the island of Qeshm to Arab Emirates, Bahrain and Oman), and across the Mediterranean (between the Arab Maghreb and southern Mediterranean countries).It has been put forward in recent years the idea of building a bridge over the Strait of Bab el Mandeb connecting Yemen and Djibouti. The Kofi Danish company had conducted a feasibility study on the possibility of implementing the project on behalf of a group of UAE companies to build it.There is also an idea to build a tunnel through the Strait of Tiran linking South Sinai at Sharm el-Sheikh and the Arabian Peninsula. And connecting the Sinai in the west to the rest of Egypt and Africa. In parallel with these lines, there should be built a common network for the transfer of electricity, natural gas pipelines and oil. In general, Arab railway lines should be of a two-track, at least, must be developed in the future to three and four lanes in order to provide future transport networks, which should last for a hundred years. It should also increase the number of rail engaged in electricity, and that is to expand the railway from $1000 \mathrm{~mm}$ width scale to the global standard scale $1,435 \mathrm{~mm}$ is necessary to connect the European and Arab Morocco network. If was completed accurately, the intensive investments on infrastructure - with an emphasis on the need for modern trains and high speed - will build the foundation for major area for cooperation between Europe and Africa and the Middle East that would turn the Mediterranean into a lake for development and peace.

\section{Second: Oasis plan... war against the desert}

The Oasis plan - as defined by the US economic "Lyndon LaRouche" - refers to a broad program includes proposed projects currently for water treatment, transportation and other projects, plus a large-scale nuclear and conventional energy use in water desalination, in addition to the establishment of the incision channel projects and the transfer of power, and to find sources of new fresh water in parts of the Middle East and the Maghreb through the creation of routes for development strategy on the scale that can be added with amounts of water for new artificial" Jordan rivers ".This means the possibility of finding the fundamental pillars for the development and lasting peace in the presence of agricultural and industrial potentials and related structures of the social infrastructure of housing, schools, health cities, cultural centers and services. There is no excuse for any government that says it is unable to build any of these before the stabilization of the situation and the arrival of the foreign investor and political change, democracy and so on. These poor excuses proved by Egypt, and Iran that they do not stand in the way of a state that decided to build its future and consolidate the pillars of strength despite the economic sanctions and terrorism, internal and external threats. The previous text highlights Chinese orientations seeking to change the global economic system as a whole, focusing on the Middle East and countries in the region in response to these trends, and therefore the region faces new variants that will contribute to changing economic and security scenes in the future, and in the following manner:

1 - increased economic and trade cooperation: the initiative in its current form puts forward and supports economic and trade cooperation between the countries on the path of the road, and to facilitate the flow of trade, leading to the unification of customs tariffs, so as to push the future towards the signing of free trade agreements, and the establishment of free trade zones in the border areas of the countries of the road, but this undermines the growing conflicts in the region, which may result in the imposition of protective duties for certain products from certain countries, or to prevent the import from the beginning, headed by Iran.

On the other hand, through the signing of memorandums of understanding with countries along the path of the road to go in the future to reflect China's moves towards the signing of one agreement of these countries with a combined, or even the establishment of an international organization for this purpose, and at the same time marginalizing the role of the World Trade Organization, which China seeks mainly through the reduction of the role of international economic institutions controlled by the West.

2 - transmission of investments from West to East: the Silk Road Project is not only reflecting improving the shape and size of trade exchange between the countries located on the track; but also attract 
investment and pump them to facilitate the route, and the establishment of a logistics and supported service projects, which pays for the transfer of capital from the West to the east, which is manifested in the participation of many European countries in the "Bank of Asia to invest in infrastructure", and therefore the bank seeks to connect European economies with the Asian economic and capital money of the Gulf for optimization of the new silk road.

3 - attempts to end the conflict in the region: the Chinese president acknowledged on more than one occasion that the development and stability go hand in hand, and therefore the current situation of the region from the chine's view, will undermine the application of the Silk Road initiative efforts, so Beijing hopes that through the new Silk Road incentive, it will contribute to the countries located on the road course to end the region's conflicts, and to resolve any tension between them within the framework of maintaining the common interests, and thus China will support any political solutions to end these conflicts, and could see the near future, more Chinese mediation with the allies Russia and Iran, in order to calm in the region to start development based on peace and mutual interests, and indications that China's recent mediation for the purpose of the truce between Saudi Arabia and Iran.

4. The new security arrangements in the Gulf region: for the security of the Arabian Gulf, is a key element in China's ambitious plan, and to the fact that the Gulf States is an important market for the marketing of their products, or for being an important transit area on the path of the Silk Road, especially with the presence of giant ports provide services logistics for ships and containers, so China will not allow infringement upon this region, but their presence which depends on the American presence, so Beijing will not leave any opportunity to increase its presence to replace the American umbrella, and may be the beginning of this presence through the competition the American monopoly of arms it sells to countries in the region, especially and that some countries had already begun to diversify its sources of arms in light of the growing conflicts and security threats in the region, and indications that Egypt and China agreement in January 2016 to supply Egypt with a list of sophisticated weapons.

5-- Security Cooperation in the road network secure: The Middle East region is facing many of the terrorist threats and other threats based on sectarian conflicts, which requires coordination and security cooperation between China and countries in the region to secure the roads, whether land or sea, as well as the face of organized crime on the length of roads, especially with regard to the smuggling of drugs and arms, which raises the need to establish entities to address these security threats along the lines of "Shanghai cooperation Organization", and thus will be China's significant role in the insurance and security coordination with the countries of the region to maintain the flow of trade between these countries.

When Chinese President visited "Hu Jintao," the headquarters of the giant Saudi company, "Aramco" last year, he did not need translators, where there were already a number of Saudi translators who speak fluent Chinese. The "Aramco" company had sent years ago, dozens of employees to study in Beijing, in the knowledge that the China-not the United States-is ultimately the market that will absorb the Saudi oil exports growing in the future. At the same time, the Saudis are sponsoring students to study in India, China, Malaysia, Singapore, South Korea, and three of these countries-India, China and Malaysia-were among the first countries that had been visitedby Saudi Arabia's King Abdullah bin Abdul Aziz after he ascended to power in his country in 2005. The Saudi students represent a small aspect of the new trade track path between the Middle East and Asia, which became known as the "New Silk Road" after the trade and investment between areas located on it were doubled four times during the past decade, it is also expected to continue and grow and be doubled dramatically annually until 2020, according to management consultant known as "McKinsey \& Company." The visit by His Highness Sheikh Mohammed bin Rashid Al Maktoum, UAE Vice President and Prime Minister and Ruler of Dubai to India. Among the dozens of agreements that have been signed during this trip there was an agreement regarding a real estate project worth $\$ 20$ billion to create three integrated residential cities on an area of 40 thousand acres in the state, "Maharashtra?"The New Silk Road is not just only lead to stimulate the economy but also to create new job opportunities for the youth sector in all participating countries in this way. It also contributes to a change of scenery geo-political, economic and geo-East and the Middle East with the formation of a new and powerful body weight behind stands is generally more serious repercussions for the policy of any external party affects the security and national strategies of the area residents. The New Silk Road grew largely due to the intersection of the economic growth of China and India with the increase in oil prices. Economic growth has resulted in the increase in oil prices to the swollen coffers of China and the six Gulf Cooperation Council (Saudi Arabia, UAE, Kuwait, Qatar, Bahrain, and Oman) with large amounts of money. Moreover, the needs of China and India's growing energy will ensure the continued growth of cooperation, which is in its entirety Council (GCC) economy, the sixteenth in terms of ranking in the world economy. According to forecasts that China will import 2025 quantities of oil from the Gulf region three times of the quantities imported by the United States. The equivalent to the old caravans centers break on the new Silk Road, it is what it is called at the moment "Regional Winners" or rising stars, which include cities such as Abu Dhabi, Dubai, Beijing, Mumbai, Chennai, Tokyo, Doha, Kuala Lumpur, Singapore, Hong Kong, Riyadh, Shanghai. 
The break old caravan centers on the ancient Silk Road, such as Persia (Iran), and the Levant (Lebanon, Syria and Jordan) and Mesopotamia (Iraq), they back down and give way to the emerging centers.

We can say that Dubai has become the unofficial capital of the Middle East on the new Silk Road after being turned into a gathering point for the funds, ideas, and traders, who pay growth forward. Iran, which was once a central force, it now turned into a sick man, although it has still a huge latent potentials.

Investors from the Gulf Cooperation Council have been pumping money into the real estate and banking industry and infrastructure in various parts of Asia. The authority of investment in Kuwaiti, for example, but not limited to, is the largest investor in the Industrial and Commercial Bank of China, has doubled its investment in Asia in the past two years. Moreover, an official in Dubai last month said that some of the Gulf Cooperation Council (GCC) is thinking of buying, "Yuan" Chinese to diversify their monetary reserves. At the same time active Chinese, Korean, Indian and Japanese companies in many areas in the Middle East, for example, real estate, consumer products and industrial investments. Furthermore, it was noted that China and Egypt, are two important countries on the ancient Silk Road, had just been awaken up, and promised to double their trade in the next few years. While the develop mindshare being made, "Nicholas Burns," US Undersecretary of the Foreign Ministry gave a statement last February in which he said that the Iraqi crisis, the Israeli-Palestinian conflict, the conflict in Lebanon, and the Iranian file are located in the heart of the concerns of the ministry in the Middle East at the moment, and that senior US officials are wasting a great deal of their time to address these crises.

It is a fair to say that all these issues are critical, but when the bureaucratic apparatus of US foreign affairs focuses mainly on extinguishing the flaming fire, it is certain that he will not have enough time to pay attention to cross-regional links. The benefits of trade are not the only benefits that America can derive from the new Silk Road, but there are other benefits, including the expansion of the scope of American security itself.

The importance of security in the Arabian Gulf region for Beijing and New Delhi today no less than its importance to Washington. China will not convince anymore to stay under the US security umbrella in the Gulf, which also applies to India, which has already begun to put patrol in the Arabian Sea. Furthermore, Americans should not forget that China and India have influence on Iran than the US influence on the state, and they have less patience to withstand the devastating war breaks out in the Gulf. Then let us not forget also that many of the political elites in the Islamic Republic are at the same time commercial elites who desperately need to find a way out of the conflict. The drawing of a path track route toward greater integration in the new Silk Road, will be effective on reducing Iranian leadership extremists, that exceeds the effect of isolating the leadership.

\section{CONCLUSION:}

Many countries in the region depend on the role of the "Silk Road" initiative to maximize the economic and social the development, but this ambitious initiative faces many challenges, most notably the Middle East situation which is not stable, as well as the dominance of the United States and its Western allies who will not leave China's freedom of movement to threaten this dominance, with this in mind that there is a tendency that the future will be to the east, both Asian countries or African, something that worries the West, and put it in confrontation with these new trends site. It is the security threats along the silk road tracks of one impediments to the success of the initiative, as well as the need to provide the necessary funding to support the initiative, and in addition to these challenges to the Chinese moves will be linked to the extent of the desire and the determination of the countries located on the path of the road on the cooperation in the success of the initiative, and the most difficult challenge for China remains to try to reset disputes between countries in the region and integrate them into one to activate and the success of the new silk road initiative of legal framework. With the continued growth of the "New Silk Road" in the east, more such opportunities will appear, but the problem is that America may be engaged in putting out the fire raging in the Middle East, to the extent that it may obscure the vision of such amortization opportunities. We are not going to review the different possibilities of the development of China's policy toward the Middle East, but to go directly to what we believe is the likely impact over the next ten years: The upcoming Chinese leadership indicates - If it is true that we expected, we pointed out to the pragmatic policy it is seeking to ensure oil market in the Middle East will remain the mainstream, and will seek to make itself a way from indulging in internal conflicts in the region. Perhaps the absence of China in the Quartet committee in charge of the settlement of the Arab-Zionist conflict indication of this trend, because china wants to maintain an equal distance from the feuding political reasons and common interests between China and the Arab states and Israel on the other. China will continue to support Iran in the strategic orientations without its consent on some of the details of this strategy, given the extreme importance of Iran in terms of market, oil imports and the force that impedes the growing of US influence in the region, which is a vital area of China. Therefore it believes that the Iranian nuclear program does not constitute a military threat yet, and that the sanctions on Iran will not stop it. China may show some leniency with the international and Arab orientation in the position of Syria, especially if it gets a rewarding trade-off from the United States, especially in Taiwan's file. However, the Russian position might be affecting the hardener China's position in this area. General Chinese assessment of US policy in the region refers to it as a policy of "doomed to failure, as the United States 
has a sense of psychological exaggerated by force, and that the US potential is less than this sense," according to said Chinese veteran diplomat (QianQichen) in the newspaper China Daily., not to mention the recent developments in the victory of President-elect Trump and started watching him very carefully. So China means that China's strategy would not mind sinking the United States in more problems in the Middle East, to the extent that reduces restrictions on Chinese diplomacy. China will continue to move towards the Arab Spring reticent to a large extent, and Beijing will work to keep this issue out of the priorities of its concerns, and will interact with it on the basis of the degree of impact on the share of the energy market. Sudan may be the next test of China's position in this area -Arab Spring-especially that Sudanese-Chinese relations is one of the advanced relations, since China is the first country in the volume of foreign investments in Sudan, which could boost China's link with Iran if it lost its influence in Sudan. Perhaps the most enduring legacy, that Silk Roads left, is its role in the convergence of cultures and peoples and to facilitate exchanges between them. Traders were forced to learn the languages of countries that have traveled through and to see the traditions in order to succeed in their trade. Thus the form of cultural interaction is a crucial aspect of the trade. These roads have seen an exchange of scientific, artistic and literary knowledge, as well as the transmission of crafts and technical tools, languages intersection, religions, cultures and mixing together. Among the most prominent technical achievements reached through the Silk Roads to the world, the art of paper-making technology printing, gunpowder and the compass, astronomy, medicine and the Arab calendar. The irrigation systems deployed in Central Asia was characterized by a distinctive characteristic that have moved Travelers who not only carry the cultural knowledge, but imbued with knowledge societies, who also pitched in them. Then religion and the pursuit of knowledge, on the other, became motivations for travel on these roads. China Buddhist priests were accustomed to traveling to India for pilgrimage and to bring sacred texts. And it represents what Donoh notes on their travels, as an important source of information, such memoranda of XuanZang (629-654), which has great historical worth. Europeans priests' were intended in the Central Middle Ages in the diplomatic and religious missions. Perhaps the Italian explorer Marco Polo is the broadest famous traveler, as he spent more than 20 years in the nomadic (between 1271 and 1292) and his listed Tests and the fighting became very common in Europe after his death. Through the Silk Roads, china plays a key role in the deployment of religions in the Eurasian region. Buddhism is the best example of these religions that traveled across the Silk Roads, as found art pieces and Buddhist shrines in as far apart as sites such as in Bamiyan, Afghanistan, and Mount Tai in China and Borobudur in Indonesia. The spread of Christianity as well as Islam, Hinduism, Zoroastrianism, Manichaeism, in the same way, the travelers drink cultures that found them and returned them back to their homes. China is exercising its international relations with the surrounding skillfully, used diplomatic inducements and economic aid, or pressure on the neighboring countries in line with its strategy and its interests in the region, and without abandoning the «sovereign rights», especially in Taiwan or in the sea China's east and south and some disputed islands with a number of coastal States for the two seas. Therefore China has launched in its international relations based on three strategies known as diplomacy, near the ocean «Peripheral Diplomacy», initiative and strategies are:- The Silk Road Economic Belt.- Maritime Silk Road of the 21st century (21st Century Maritime Silk .Road - Bangladesh economic track paths - China - India - Myanmar, Bangladesh - China - India - Myanmar (BCIM) Economic routes .The aim of this initiative is to enhance cooperation and regional commercial and financial and international communication, and to the development of cultural and civilization ties between peoples. This is singled out in China and the Far East, but in regard to the Middle East and the Arab world, also china has «silk dreams». Researcher, Suleiman Zhou LES, director of the Arab Center for Studies in International Studies University in Beijing, sees that the Arab world is a convergence of the ways offshore and onshore silk point, so it sees as a natural partner in the creation of the new Silk Road. Chinese cooperation - Arab sides will contribute to the collection of capabilities, in terms of financial resources and the advantages and potential of the market, and in the promotion of free and regular flow and optimum distribution of resources between them. If we know that the Chinese initiative seeks to establish the infrastructure of roads and communication networks, power lines, service facilities, security along the way and linked with each other, creating a new environment for investment, tourism and international, regional trade barrier-free, deepen financial cooperation in order to build a stable of cash, exchange, transfer system , linking the peoples of the countries located on the road to the interests of expediency and links shared, and respond to acts of piracy on the sea side of the road in order to restore the security of waterways tanker trade exchanges. If we also learned that these goals capable of creating thousands of jobs, and community development, and prosperity of the cities along the way, the Gulf states would gain a lot, especially in light of what is currently exposed or future threats, and the face of economic difficulties, and what ails relations with traditional allies of the concerns, and what prevails among youth unemployment, and seeks to diversify the sources of income. The truth is that we must understand in this context is that China, like other international powers, do not pose a huge initiatives of this kind only pioneered asa special interest, but that the Chinese, with respect to this partial specifically, proved in many corners that their interests are above all else, and that the interests of the partner party does not have the importance they have. Hence we can say that the revival of the Silk Road Project 
(founded in 1877 and has played a role in the prosperity of the ancient Chinese, Indian, Egyptian and Romanian cultures) primary objective is that China will play a more influential role in the world strategies in line with the spectacular economic ascent, and restores its laurels bygone days to cert commercial convoys to the world to market the silk which was discovered about 3000 years BC, as the presence in the region through which the road, a vast region located between the Caspian Sea and the Arabian Gulf and Red White and Bahrain, and is characterized by economic resources and huge corridors business strategy would have it. However, this fact that should not upset us is that the more savvy and policy we can adapt the Chinese way of our goals is also useful. For example, possible to persuade the Chinese to invest in the non-oil projects (such as new technologies and renewable energy projects and manufacturing military and the development of human capacity rail transport, shipping and satellites) in return of exchange for and providing oil, gas and petrochemical. On the other hand, we can also persuade the Chinese by pressuring on their Iranian partner to curb extremism and its terrorism in exchange for allowing it to play a greater role in the Shanghai Cooperation Organization for regional cooperation, and to take advantage of the Silk Road projects, particularly the construction of the proposed oil pipeline from Kazakhstan through Turkmenistan project down to Iran. Perhaps what is in our interest and is in favor of Tehran is that the Silk Road initiative essentially concerned with the prosperity and the rise of new cities on the Silk line such as Dubai, Abu Dhabi and Doha, Jeddah, Cairo, Mumbai and Karachi and Shanghai, leaving behind cities break the old caravan, such as the cities of Persia, Syria, Yemen and Mesopotamia. Finally, the Gulf States should not comply with US pressure that it may see in this initiative encroachment on their interests in the region and an opportunity for the Chinese to extend its influence to the world. The initiative, if achieved, as is hoped capable of creating a new reality, Limoges employment opportunities, development and prosperity, and the centers of money and ideas, industries and businesses, and thus head off the frustration that leads to extremism and terrorism, that we complain about it.

[1] Balázs Sárváril Anna Szeidovitz,(2015), The Political Economics of the New Silk Road, Corvinus University of Budapest Fővámtér 8, Budapest 1093, Hungary.

[2] Valerie Hansen,(2012), The Silk Road: A New History, Oxford University Press, USA.

[3] John Garver (2008), The Vital Triangle: China, The United States and the Middle East. Washington, DC: Center for Strategic and International Studies.

[4] Peter Frankopan,(2015)The Silk Roads: A New History of the World,UK,Bloomsbury.

[5] Colin Thubron, The Lost Heart of Asia, UK,Harper Perennial.

[6] Lawton, J., ed. (2008), Integral Study of the Silk Roads: Roads of Dialogue, Paris: UNESCO. Retrieved from http://unesdoc.unesco.org/images/0015/001592/159291eo.pdf [accessed Oct 2015]

[7] Laruelle, M. (2015), 'The Chinese Silk Road and their Reception in Central Asia,'Testimony before the U.S.-China Economic and Security Review Commission Hearing on 'Looking West: China and Central Asia.' Retrieved from http://www.uscc.gov/sites/default/files/Laruelle\%20Testimony_3.18.15.pdf [accessed Oct 2015].

[8] Hansen, V. (2012), The Silk Road: A New History, Oxford: Oxford University Press.

[9] Li, J. (2014), 'Report: Silk Road Economic Belt may be divided into three phases; initial completion predicted in 2049,' ZhongguoXinwen Wang, 28 June.

[10] Liu, X. (2010), The Silk Road in World History, Oxford: Oxford University Press.

[11] Liu, Z. (2014), Central and Eastern Europe in Building the Silk Road Economic Belt, Working Paper Series on European Studies, Institute of European Studies, Chinese Academy of Social Sciences, vol. 8, no. 3 .

[12] Marshall, G. (1947), Speech given by United States Secretary of State, General George Marshall at Harvard University, 5 June.

[13] Matura, T. (2012), 'The pattern of Chinese investments in Central Europe,' International Journal of Business Insights \& Transformation, Special Issue, vol. 5, no. 3, pp. 104-109.

[14] Maxxelli Consulting (2015), West China's International Railway Development. Retrieved from http://www.maxxelli-consulting.com/west-chinas-internationalrailway-development/ [accessed Oct 2015]

[15] Men, J. (2015), “China's New Silk Road and EU-China relations,” in EU-China Observer, no. 1.15, pp. $12-15$.

[16] Messenger (2014), 'Reimagining the Silk Road,' vol. 25, no. 5. Retrieved from http://issuu.com/nicktsui/docs/messenger_silkroad_for_issuu [accessed Oct 2015]

[17] van der Putten, F.-P. \&Meijnders, M. (2015), 'China, Europe and the Maritime Silk Road,' Clingendael Report, 26 March. Clingendael: Netherlands Institute of International Relations. http://www.clingendael.nl.

[18] Rolland, N. (2015), “China’s New Silk Road,” The National Bureau of Asian Research (NBR), 
[19] Schweisgut, H. D. (2015), 'EU-China 40th Anniversary: Expectations for Expanding Connections, in EU-China Observer.

[20] Staburova, J. \&Bērziņa, U. A. (2013), 'Glimpse at EU-China relationships since 2008,' Baltic Journal of European Studies, vol. 3, no. 1.

[21] Stahl, A. K. (2015), “China’s New Silk Road Diplomacy: Implications for China's Relations with Europe and Africa," in EU-China Observer.

[22] Szczudlik-Tatar, J. (2013), China’s New Silk Road Diplomacy, PISM Policy Paper, no. 34 (82). Retrieved from https://www.pism.pl/files/?id_plik=15818 .

[23] Tao, X. (2014), “Back on the Silk Road: China's version of a rebalance to Asia,'Global Asia, vol. 9, no. 1. Retrieved from http://www.globalasia.org/wp-content/uploads/2014/03/548.pdf.

[24] The World Bank (2015), The World Bank Investor Brief. Retrieved from http://treasury.worldbank.org/cmd/pdf/WorldBankInvestorBrief.pdf .

[25] TRACECA (2012), Silk Wind: The Route of Multimodal Block Train (Project Progress Presentation), National Secretariat of IGC TRACECA in the Republic of Kazakhstan. Retrieved from http://www.traceca-org.org/uploads/media/14_Presentation_Silk_Wind_07-11-12_eng.pdf .

[26] Turcsányi, R. (2014), 'Central and Eastern Europe's courtship with China: Trojan horse within the EU?’ EIAS: EU-Asia at a Glance, January. Retrieved from: http://www.eias.org/sites/default/files/EUAsia-at-a-glance-Richard-Turcsanyi-China-CEE.pdf .

[27] Brian Hook (Ed.) (1990)'The Cambridge Encyclopedia of China', Cambridge U.P.

[28] Txabarriaga, R. (2010), 'Implications of increasing Europe's trade with China, Tcworld, February. Retrieved from http://www.tcworld.info.

[29] Vangeli, A. (2015), “China's New Silk Road and its impact on Sino-European relations,"in EU-China Observer, vol. 1.15.

[30] Värk, J. (2013), 'Russia between China and the European Union: Friends or Foes?' Baltic Journal of European Studies, vol. 3, no. 1(13), pp. 29-43. http://dx.doi.org/10.2478/bjes-2013-

[31] Railway Road Connections Map (2005), 'Railway and Road Corridors Connecting the Central Asia Regional Economic Cooperation Member Countries,' [image] Central Asia Regional Economic Cooperation. Retrieved from http://www.carecprogram.org

[32] Railway Gazette (2015), 'DB Schenker launches Hamburg-Zhengzhou train,'5 September. Retrieved from http://www.railwaygazette.com.

[33] Wang, J. (2012), "'Marching towards the West', China's geopolitical strategy of rebalancing," HuanqiuShibao.

[34] Ministry of Foreign Affairs of the People's Republic of China (2013), President Xi Jinping Delivers Important Speech and Proposes to Build a Silk Road Economic Belt with Central Asian Countries, 7 September. Retrieved from http://www.fmprc.gov.cn/mfa_eng/topics_665678/xjpfwzysiesgjtfhshzzfh_665686/t1076334.shtml.

[35] Waugh, D.C. (2010), 'The silk roads in history,' Expedition, Special Issue: Silk Road, vol. 52, no. 3, pp. 9-22. Retrieved from http://faculty.washington.edu/dwaugh/publications/waughexpeditionfinal.pdf [accessed Oct 2015]

[36] Wood, F. (2002), The Silk Road: Two Thousand Years in the Heart of Asia, Berkeley, Los Angeles: University of California Press.

[37] Xu, G. (2014), "Looking at the 'One Belt, One Road' strategy from a return on investment point of view,” Financial Times (Chinese version), 20 November.

[38] Yang, Y. (2015), 'China-EU Relations: Broader, Higher and Stronger,' in EU-China Observer, vol. 1.15 .

[39] Yiping, H. (2015), "Don't Let 'One Belt, One Road' Fall into the Trap of Japan's Overseas Investments," ZhongguoGaige Wang.

[40] Zhang, J. (2015), “China's pursuit of a new economic order,' Project Syndicate, 2 June. Retrieved from http://www.project-syndicate.org/commentary/china-new-worldorder-by-jun-zhang-2015-

06?barrier=true [accessed June 2015] Zheng, X. (2014), “'One Belt, One Road' is not 'China's Marshall Plan'," Huanqiu Wang.

[41] Zheng, Y. (2015), "The 'One Belt, One Road' strategy helps the world economy rebalance," LianheZaobao / Oriental Morning Post, 8 January.

[42] Peter Hopkirk, (1980), 'Foreign Devils on the Silk Road', Oxford U.P.

[43] 'China: A Guidebook to Xinjiang', Xinjiang Educational Press, Urumqi 1988.

[44] Mohammad Salim Al-Rawashdeh,THE IMPACT OF THE INFORMATION REVOLUTION ON INTERNATIONAL RELATIONS. Global Journal of Political Science and Administration Vol.2, No.5, pp. 1-22, December 2014 Published by European Centre for Research Training and Development UK (www.eajournals.org). 
[45] Dr. Al-Rawashdeh Mohammad Salim,The United States-Chinese Relations (The Chinese Dragon and the USA Eagle).International Journal of Humanities \& Social Science Studies (IJHSSS) A PeerReviewed Bi-monthly Bi-lingual Research Journal ISSN: 2349-6959 (Online), ISSN: 2349-6711 (Print) Volume-II, Issue-III, November 2015, Page No. 24-49 Published by Scholar Publications, Karimganj, Assam, India, 788711 Website: http://www.ijhsss.com.

[46] The international politics journal, Egypt, Cairo.

[47] Al-Rainews paper, Jordan Amman.

[48] Albayian news papr. UAE.

[49] Aldostoor news paper . Jordan -Amman.

[50] Alahram news paper,Egypt-Cairo.

[51] Al-qudos news paper, Kuwait.

[52] Jordan Times, Jordan-Amman.

[53] Al-sharq Al-Awsat News paper .Lebanon. 